wise cause injury. I conceive that this seventh or combined sense stands in the same relationship to consciousness as impulse does to reason. Consciousness per se would often be too late to be of service. But this seventh sense, once set in motion, awakens consciousness, which can then, if necessary, call the will to its aid. It would be easy to enlarge upon this, and my theory would not be denied with regard to merely mechanical movements and rigid points of contact. But this protective influence of the combined senses does not stop here; it is constantly called into play instinctively when other than mechanical injury is threatened. Who does not hold his breath involuntarily when he smells a stench? I do not know if it has before been definitely stated in so many words, but it is a fact that respiration is the only vital function that is under the immediate command of the will. It is in itself a striking fact, and the effects following are no less striking. By the exercise of this power of the will over the respiratory acts the blood pressure can be raised or lowered at will. Who does not know that a few prolonged inspirations will induce such a condition of faintness that a small surgical operation can be performed without pain? On the other hand, by restraining the respiration, as in the act of sipping a glassful of water (vide Lauder Brunton), the blood pressure is very notably increased. Who can doubt that this is a means of protection against a thousand evil influences that no single one of the five or six senses could detect, but of which we are made more or less conscious through their combined action? For my part, I know that when I have to visit an infectious case I breathe slowly and carefully, and waste as little breath as I can till I am in fresh air again. Now, during sleep the will and all the senses are in abeyance, and the poor lungs are left to take care of themselves as best they may. I am, Sirs, yours obediently,

St. Olare's Union Infirmary, May 8th, 1888 .

R. J. SHEPHERD, M.D.

P.S.-Mr. G. Fleming, F.R.C.V.S., in his letter on "Bovine and Human Tuberculosis" (Se日 THE LANCET, April 7th, 1888.), mentions the prevalence of tuberculosis amongst the choicest breeds of cattle. It would be interesting to know how these cattle are housed, and if over-ventilation, especially at night, has robbed them of the necessary amount of warmth.

\section{THE STOMACH-PUMP SUPERSEDED.}

\section{To the Editors of THE LANCET.}

SIRs,-The recent correspondence as to the use of covered funnels in feeding by the stomach tube leads me to give greater publicity to a far better contrivance, which I devised many years ago, and constantly use here. An ordinary twentyounce bottle, perforated near the bottom by a small tap for the admission of air, and a long stomach tube bearing a cork

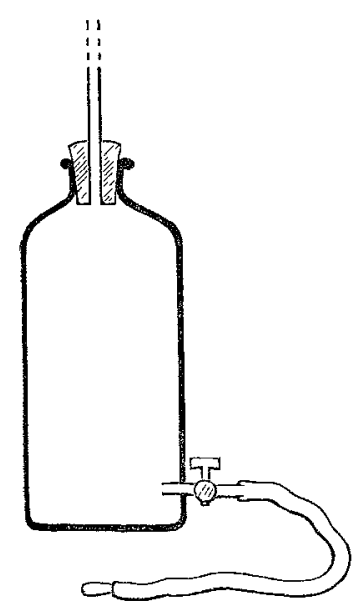
which fits the mouth of the bottle, constitute the whole apparatus. The food being mixed in the bottle, the tube is introduced, the cork placed in the mouth of the bottle, the bottle inverted and raised, and the air-tap opened, when the food passes quickly into the stomach in a continuous stream. Great injecting force can be at once applied if required by blowing through the air-tap, to which a small rubber tube is attached for this purpose. For simplicity, cleanliness, efficiency, and perfect inspection this plan leaves nothing to be desired, and solid nourishment can be thus given in many forms, as there is no tap to obstruct its passage, and as the food can be kept in agitation within the bottle during administration. No one who has used this contrivance will wish for any other. It is equally available for emptying the stomach by lowering the bottle and establishing a syphon action by suction. Messrs. Hilliard and Sons, Glasgow, supply the apparatus, which is represented in the engraving.-I am, Sirs, yours truly,

$$
\text { D. YELLOWLEES, M.D. }
$$

Royal Asylum, Gartnavel, Glasgow, May 12th, 1888.

\section{SIR WALTER SCOT' AND HYDATID DISEASE.}

\author{
To the Editors of The LANCET.
}

SrRs,-The indications in "Lockhart" that Scott was a victim to hydatid disease seem to have been overlooked. His constant intimacy with dogs is well known, but it was not till many years after his death that dogs were known to be the source of hydatids. The extracts are from the first edition, in seven volumes, but the dates as given will assist verification. I give them in their natural order, with the exception of the post-mortem examination, to be found in a foot-note towards the end of the work.

Vol. vii., p. 394: "Abbotsford, Sept. 23rd, 1832. - This forenoon, in presence of Dr. Adolphus Ross from Edinburgh, and my father, I proceeded to examine the head of Sir Walter Scott. On removing the upper part of the cranium, the vessels on the surface of the brain appeared slightly turgid, and on cutting into the brain the cineritious substance was found of a darker hue than natural, and a greater than usual quantity of serum in the ventricles. Excepting these appearances, the right hemisphere seemed in a healthy state, but in the left, in the choroid plexus, three distinct though small hydatids were found, and on reaching the corpus striatum it was discovered diseased, a considerable portion of it being in a state of ramollissement. The bloodvessels were in a healthy state.-J. B. Clarkson."

In regard to the extracts which follow, $I$ have the remark to make that there is no allusion to gall-stone disease in the whole work.

Vol. iv., p. 57: “Edin., March 20th, 1817.-I had been plagued all through this winter with cramps in my stomach, which I endured as a man of mould might. . . . On the 5th I had a most violent attack, which broke up a small party at my house, and sent me to bed roaring like a bull calf. . . At length the symptoms became inflammatory, and dangerously so, the seat being the diaphragm."

Vol. iv., p. 231: "It had been Scott's purpose to spend the Easter vacation (1819) in London, and receive his baronetcy; but this was prevented by the serious recurrence of the malady, which so much alarmed his friends in the early part of the year 1817, and which had continued ever since to torment him at intervals."

Vol. iv., p. 237 (to Southey, April 4th, 1819): "I have gone through a cruel succession of spasms and sickness, which have terminated in a special fit of the jaundice. ...... If I had not the strength of a team of horses I could never have fought through it."

Vol.iv., p. 244 (to the Duke of Buccleuch, April 15th, 1819): "My whole left leg was covered with swelling and inflammation; ...... my right leg escaped better." About this time Lockhart visited him at Abbotsford.

Vol. iv., p. 259: "He had lost a great deal of flesh; his clothes hung loose about him; his countenance was meagre, haggard, and of the deadliest yellow of the jaundice; and his hair, which a few weeks before had been but slightly sprinkled with grey, was now almost literally snow-white." These painful attacks recurred for months. At last they left him, and for some years he enjoyed good health.

Vol. V., p. 320 (1824): "His woods were now in such a state of progress, that his usual exercise out of doors was thinning them. $\mathrm{He}$ was an expert as well as powerful wielder of the axe, and competed with his ablest subalterns as to the paucity of blows by which a tree could be brought down, ........ and if he had taken, as he every now and then did, a whole day with them, they were sure to be invited home to Abbotsford to sup gaily at Tom Purdie's."

As the general symptoms of chronic brain disenses are very much alike, it is hardly necessary to quote passages to show the course of the final illness, which lasted from February, 1880, till September, 1832 . The convulsive attacks called apoplectic would now be probably called epileptic. For example:-

Vol. vii, p. 238: "Towards the end of November, Sir Walter had another slight touch of apoplexy. He recovered himself without assistance." Scott says in reference to this attack (p. 242), "I had a slight vertigo when going to bed, and fell down in my dressing-room, though but for one instant."

There seems to be no evidence that any other members of Scott's household suffered from hydatid disease; but it looks suspicious that so many deaths happened in the family about the same time. Lady Scott died in 1826, 
"asthmatic complaints terminating in hydropsy." Miss Anne Scott, in 1833: "brain fever," preceded by occasional fits for a year or two. Mrs. Lockhart, in 1837, "after a long illness."

Chobham, April, 1888. $1 \mathrm{am}$, Sirs, yours truly, JOHN HOPw, M.D.

\section{ELECTRIC ILLUMINATION OF THE BLADDER. To the Editors of THE LANCET.}

Sins,-Dr. Nitze, in your issue of May $12 \mathrm{th}$, states his belief that $I$ have given unfair prominence to $\mathrm{Mr}$. Leiter in the history of electric endoscopy. Dr. Nitze is greatly mistaken. I cannot believe that he has seen an abstract of my lectures upon the subject (delivered in January and February last), which was in print prior to Dr. Nitze's first appearance in the English medical press (THE LANCET, April 21st, 1888). I have there described the method as "The Nitze Method." I have, moreover, drawn especial attention to the value of his work, and have referred to him as "the able introducer of this brilliant innovation." 1 endeavoured thus to give honour where honour was due. I must now decline any further correspondence with Dr. Nitze on the subject.

I am, Sirs, yours faitbfully,

Old Burlington-st., May 12th, $1888 . \quad$ E. HURRY FenwICK.

\section{OSTEO-PLASTIC RESECTION OF THE FOOT BY THE METHOD OF MIKULICZ.}

To the Editors of THE LANCET.

SIRs,-I was very much interested in reading the paper by Sir William Mac Cormac in your issue of May 5th. The case reported reminds me of one which I published in your journal of July 10th, 1886 (vol. ii., p. 71), in which I removed os calcis, astrágalus, and both malleoli by a posterior median and horseshoe incision, without attempting, however, to obtain ankylosis, and yet getting what was very much better - a perfectly movable false joint. The operation was performed in the $y$ ear 1882 , and I showed the case before the Leeds and West Riding Medico-Chirurgical Society in 1886. My patient at the present time, six years after the operation, can walk without a limp and is in perfect health. The operation, as far as I was concerned, was a perfectly original one, and was really brought about by the exigencies of the case. I have, however, always felt that if I again met with a similar case I should not hesitate to do the same operation. Of course I would not venture for one moment to criticise the operation reported by Sir William Mac Cormac, but I have never heard of a similar. operation to my own being performed, and should be glad to know if, generally speaking, there can be any sound objection to my method of operating in cases requiring resection of the foot. I will only add that I shall be pleased to forward to yourselves or to Sir William Mac Cormac the specimen of bone which I removed. I remain, Sirs, yours obediently,

Batley, Yorkshire, May 10th, 1888. AlFRrd SWaNn, M.D.

\section{"ANOREXIA NERVOSA." To the Editors of THr LANCET.}

SIRs,- - The following case may be of interest as an example of this newly recognised condition.

The patient was a weakly, emaciated lady, capable of doing a fair amount of work when not interfered with, but the slightest interference was quite sufficient to disturb her normal equilibrium. It was then that certain curious phenomena manifested themselves. They usually commenced with intense headache and a peculiar cold feeling in the region of the heart, which ultimately extended itself throughout the body, leaving the extremities very pale in colour. This was especially so as regards the lobes of the ears, which were almost as white as chalk. These sensations were followed by a constant dribbling of urine, of ten sufficient to saturate two dozen napkins daily. Towards the close it became more or less limpid, and was usually accompanied by a sharp attack of diarrhoea, leaving the patient well until the next disturbance, which never occurred without some assignable cause. There was a great distaste for food, the patient going for days without taking anything beyond hot water. Amenorrhoa was also present. This lady some time ago went to live in a farmer's house some miles a way, was forced to take "plenty of milk and fresh eggs," and came home very much improved. She is now having the massage treatment, and is improving daily, Since going a way there has been no return of the symptoms alluded to. I am, Sirs, yours faithfully,

Liverpool, May 14th, 1883. $\quad$ T. G ERALD GARRY, M.D.

\section{LUNAOY CERTIFICATES. \\ To the Editors of THE LANCET.}

SIRs,--I thiuk that medical men have reason to be grateful to you for the powerful manner in which you put their case in this matter. I think it is eminently desirable that they should one and all refuse to sign any more of these certif. cates in the existing state of the law. It is monstrous that a man should be mulcted in hundreds of pounds for signing a lunacy certificate when the Court has decided that in so doing he acted on sufficient grounds and conformably to the law. I agree with you that there is no cowardice or dereliction of duty in refusing to perform a service to the State when the State refuses to protect you in the same. If we as citizens have our duties to the State, the State has also its duties towards us, and it is the plain and manifest duty of the State, when we have legally and on sufficient grounds signed a lunacy certificate, to protect us from any pecuniary losses attending any subsequent legal proceedings. And I would suggest that before a person is permitted to institute an action of this kind he should be required to deposit securities for the payment of the defendant's casts in the event of his losing his action. Yours faithfully,

Stroud-green-road, N., May, $1888 . \quad$ R. Robinson, M.R.C.S.

\section{$\longrightarrow$ \\ LIVERPOOL. \\ (From our own Correspondent.)}

\section{DEATH OF DR. ARTHUR CRESSWELI RICH.}

THe death of Dr. Arthur C. Rich in his thirty-second year is an event which, though not unexpected, came as a great shock to all his numerous professional and lay friends this afternoon. The deceased was the eldest son of the wellknown and highly respected postmaster of Liverpool, Mr.J.D. Rich, and after being educated at King William's College, Islo of Man, he commenced his medical education at the Liverpool School of Medicine. From the very commencement of his professional career his kindly and obliging disposition made him a general favourite, and throughout the whole of it his conduct was marked with the most exceptional zeal and enthusiasm. After having passed the College of Surgeons, he became one of the house surgeons of the Royal Infirmary, and subsequently for a short period he was attached to the Birkenhead Borough Hospital. Having spent some months as resident medical officer in a lunatic asylum, he obtained an appointment as surgeon to one of the Pacific Steam Navigation Company's steamers, and afterwards to one of the steamers of the Orient line. After travelling in the United States and Canada, he returned to England and studied at St. Thomas's Hospital, London, where he was clinical assistant to the late Dr. Murchison, subsequently passing the M. B.Lond. with first class honours. Returning to Liverpool, be obtained the important appointment of medical officer to the male cfficers of the Liverpool Postal and Telegraphic Establishment, the duties of which he discharged till within ten days of his death: He was also assistant-surgeon to the Hospital for Cancer and Skin Diseases, and pathologist of the Royal Infirmary for four years. He was also lecturer and examiner to the St. John Ambulance Association, and his death will be deeply deplored by the Liverpool police, many members of which body he instructed. For some time he had been in failing health, and there can be no doubt that his very promising career has been cut short by his self-sacrificing zeal to his profession. He suffered from successive attacks of pyæmia while performing his duties as pathologist at the infirmary, the effects of which were probably aggravated by a malarial fever formerly contracted in South America. In his last illness he was attended with unremitting care by his friends, Drs. Carter and Macalister, and passed peacefully away without pain. He was married not very long ago, and much sympathy is felt for his widow, as well as for his father and mother. 